\title{
Sophia's choice: Debt, social welfare, and racial finance capitalism
}

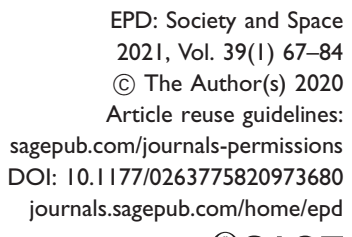

(S)AGE

\author{
Erin Torkelson (D) \\ University of the Western Cape, South Africa
}

\begin{abstract}
In this article, I examine normative assumptions about cash transfers as public goods and the lived experience of cash transfers as private debts. Policy makers and social scientists often assume cash transfers are apolitical, value-neutral monetary instruments, which improve upon inappropriate, top-down, universalizing development projects. Instead, I show how cash transfers introduce their own universals, by imagining liberal sovereign subjects, who use credit and financial markets to manage their own financial and developmental needs. I argue that this narrative elides the deep historical and geographical production of racial difference through credit and debt in South Africa's Western Cape farmlands. I call this phenomenon racial finance capitalism. First, I trace how coloured people have been racialized as debtors for the benefit of capital accumulation across generations. Then, I explore how the contemporary spatial and temporal realities of cash transfer distribution continue to racialize grantees as debtors and dispossess them of their social entitlements. Finally, I demonstrate how grantees draw upon transgenerational experiences of debt to challenge the continued social reproduction of themselves as debtors. Some South African social grantees demand recognition that they are, and have been, net creditors to the nation.
\end{abstract}

\section{Keywords}

Debt, cash transfer, South Africa, social welfare, racial finance capitalism

In February 2017, Sophia Daniels ${ }^{1}$ attended a workshop led by a social justice organization ${ }^{2}$ in the Western Cape farmlands. With her baby on her hip, Sophia explained how her children had not received their cash transfers in four months. Every night, after begging a few slices of bread from her neighbours, she considered a hellish home-economics

\footnotetext{
Corresponding author:

Erin Torkelson, Department of Geography, Environmental Studies and Tourism, University of the Western Cape, Robert Sobukwe Road, Bellville, Cape Town 7535, South Africa.

Email: etorkelson@uwc.ac.za
} 
equation: should she split the bread between her three older children $(8,13,16$ years), or eat a slice herself to breastfeed her baby (6 months)? As the months wore on, Sophia diverted her resources to her older children and her milk dried up. Her baby's weight dropped from 11 to $8 \mathrm{~kg}$ and the clinic nurse threatened to take her children into care (Torkelson, 2017).

Sophia's choice was necessary because of unjust debts accrued on her social grant. Employed in a fruit processing plant, she was forced to take unpaid leave while pregnant. Around the same time, her home burned down and she gave birth at a women's shelter. The blaze destroyed her identity documents, preventing her from registering her son's birth and applying for his grant. Struggling to support four children on three grants (R1080/\$78 per month), Sophia borrowed money from two cash lenders, using these loans to rent a wooden shack to live in. Her creditors automatically debited her bank account, seizing her entire grant in loan repayments for four months (Torkelson, 2017). She now had a home, but no way to feed those housed inside.

Sophia's family metabolized the contradictions of the financialization of South Africa's cash transfer program. ${ }^{3}$ The largest in the developing world by GDP ( $\$ 11$ billion/year), South Africa's social grants support 18 million citizens (33\% of the population), 85\% of whom are black and coloured women (StatsSA, 2018, 2011). ${ }^{4}$ Grants are means-tested, unconditional and targeted towards the caregivers of children, elderly and disabled people. From 2011 to 2018, the South African Social Security Agency (SASSA), contracted a multinational corporation, Cash Paymaster Services (CPS), a subsidiary of Net1 UEPS Technologies (Net1), to distribute grants, privatizing one of the most important public services in the country. Development experts lauded this public-private partnership as heralding a future of more equitable distribution through financial inclusion (e.g. IFC, 2016). Yet, while grantees gained small monthly incomes, Net1 gained monopoly control over the personal data and bank accounts of 18 million people, using this advantage to aggressively market loans. Grantees typically borrowed money for immediate needs (food, clothing, rent) and not for developmental purposes (small businesses). Their debts were only repayable through the regularity and security of the next month's social grant payment, not earnings on an investment. These loans were nearly risk-free for Net1, who controlled the cash flow from the National Treasury to grantee accounts, and deducted loan repayments before transferring money to recipients (Torkelson, 2020). ${ }^{5}$ Many grantees disputed these deductions, but Net1 offered limited customer service and accountability. ${ }^{6}$

South Africa's social grant program aligns with contemporary development orthodoxy oriented toward (just) giving money to the poor (Hulme et al., 2012). This common-sense narrative (c.f. Ferguson, 2015; Hulme et al., 2012) suggests that cash transfers are preferable to large-scale development projects, which are expensive, top-heavy and inattentive to local contexts. Cash transfers are imagined to side step such universalizing initiatives through the value-neutral distribution of money; and recipients are imagined to use this money to choose their own financial and developmental priorities (Collins et al., 2009). Such analyses obfuscate how cash transfers introduce new universals appropriate to a global economy driven by finance capital. Scholars and policy makers claim that cash transfers should be bundled with financial products and credit to make the most of their cash transfer payments (Clemence and MacLellan, 2017; Collins et al., 2009). As such, grantees are simultaneously excluded from the formal economy (as workers), and 'included' in the financial economy (as debtors). Neither apolitical nor innocent, such boosterism fails to consider the deep histories of the production of difference through debt and finance capital.

In this article, I offer an abbreviated racial history of debt in South Africa's Western Cape farmlands. Following Malini Ranganathan (2019), I develop the term racial finance capitalism $^{7}$ to show how finance capital has long been part of the way South Africans have 
been racialized. I build on Cedric Robinson's (2000) [1983] insight that all capitalism is 'racial capitalism'. According to Robin Kelley (2017), Robinson drew the term racial capitalism from his engagement with South African scholarship of the 1970s (c.f. Legassick, 1974; Magubane, 1979; Wolpe, 1972). While South Africans sought to understand the particularities of the apartheid economy, Robinson took a longer historical view, arguing that European feudal societies, out of which capitalism developed, were already racialized. Capitalism worked through pre-existing racial hierarchies because accumulation - i.e. capitalism's rasion d'être - depended upon the maintenance of inequalities (Melamed, 2015). His centuries-spanning analysis demonstrated how capitalism requires racism to justify the exposure of some social groups to unequal life chances and premature death (Gilmore, 2007). This happens through the obviously racist structures of slavery, colonialism and mass incarceration, but also through supposedly 'de-racialized' or 'colourblind' social programs, where human life continues to be differentially valued to meet the needs of state capitalist orders (Gilmore, 2007). Since the subprime mortgage crisis of 2008, Global North scholars have increasingly attended to the role of racism in financialization (c.f. Chakravartty and Da Silva, 2012; Kish and Leroy, 2015; Wyly et al., 2009). In the Global South, far less has been written about racism and financialization, concentrating more on poverty and gender (c.f. Elyachar, 2005; Karim, 2011; Roy, 2010).

Thinking with the historical geographies of the Western Cape, I demonstrate how finance capitalism racialized South Africans to disqualify them as 'owners' of property and 'managers' of income, allowing their possessions to be targeted for expropriation across time. This was true in the labour-scarce economies of colonialism and apartheid, and continues to be true under conditions of high unemployment today. While black and coloured people were barred from formal credit under apartheid, ${ }^{8}$ democracy brought the expansion of lending to all workers, particular those in the public service sector, who had regular, secure government incomes (James, 2014). However, South Africa's 30\% unemployment dramatically limited formal credit markets that only targeted workers - until Net1 began lending money to grantees, who also had regular, secure government incomes. As Ruth Wilson Gilmore (2007) argues when economic crises produce 'surpluses' - of land, labour, finance or state capacity - capital works to transform these idled resources into profits. In this case, black and coloured women were effectively excluded from the labour market but included in the financial market via the cash transfer program. Funded by the state, Net1 turned social grantees into a lucrative and risk-free market to absorb surplus capital in the form of credit. Though Net1 describes itself as a sophisticated financial technology company, their profits from credit were not based on high-tech algorithms or machine learning (c.f. Amoore, 2009; Noble 2018), but were relatively simple and old-fashioned. Net1 capitalized on existing inequalities embedded within South African geographies. Most poor South Africans still live in apartheid's racially defined enclaves in close proximity to one another. Net1 used its proprietary access to data about social grantees to target them for loans, and collected their debts automatically through their grant payment monopoly. The mobility differential between grantees and creditors allowed Net1 to appear to be delivering a product appropriate to the people it was meant to serve. ${ }^{9}$ Instead, Net1 exploited South Africa's sedimented racial geographies to 'predate' (Taylor, 2019) upon the social grant incomes of black and coloured women. ${ }^{10}$

Contrary to understandings of debt as divisive and individualizing, recent analyses have focused on the shared experience of debt as a basis for collective organizing (Appel et al., 2019; Graeber, 2012; Harney and Moten, 2013). Sophia and other grantees used the multivalent meanings of debt - as an economic, political, social and generational concept - to creatively theorize about their ongoing vulnerability to racial financial capitalism. 
When speaking of Net1, they wove complex narratives that transcended linear time and space, recalling the multiple forms of debt they and their ancestors suffered. ${ }^{11}$ Referencing this trans-generational repetition of debt, grantees challenged the reproduction of racial financial capitalism through the social welfare program. They countered that they were not debtors, but net creditors to the nation, through centuries of stolen land, labour and lifeways. In this way, debt became a terrain of struggle over who owes what and to whom. My interlocutors did not only think about debt as a racially constituted harm (McKittrick, 2011), but also invoked debt's multivalent meanings to challenge its reproduction. Not enough has been written about the lived experience of debt (as called for by Gabor and Brooks, 2017). As such, I focus on racial financial capital and the subject-making power of trans-generational indebtedness.

This article is based on three years of ethnographic research into debt and social grants alongside the Black Sash, a 65-year-old social justice organization. Between 2011 and 2018, the Black Sash documented thousands of cases of structural financial abuse, and I documented over 200. While I could make this argument with many stories, I have chosen to focus on two: Sophia and her neighbour Joseph. In February 2017, Sophia, Joseph and I travelled with Esley Philander (Black Sash Communications Manager), Erna Curry (radio journalist) and Johann Abrahams and Clinton Daniels (documentary film-makers) to examine how the welfare system produced debt. We worked with Sophia and Joseph to create an archive of evidence - call centre records, bank statements, receipts and contracts - to fight back against their indebtedness. We made a documentary for the South African Broadcasting Company's (SABC) Cutting Edge that was viewed by over 1 million people (Black Sash et al., 2018). This article considers the off-camera moments that did not fit our 22-minute report.

\section{Racialization through debt in the Western Cape farmlands}

During the formation of apartheid, the racial classification of 'coloured' was institutionalized through the Population Registration Act [No 30 of 1950], which specified the terms of descent for 'White', 'Native' and 'Coloured' people (with 'Indian' as a subset of 'Coloured'). After the Second World War, apartheid planners did not defend the biological essences of scientific racism (Dubow, 1995), and rather 'made' race as a political, economic and legal construct to justify white minority rule (Posel, 2001). People racialized as 'coloured' were never homogenous and included descendants of the indigenous Khoi nations; enslaved people from Indonesia, India, Mozambique and Madagascar; and indentured workers from India and China. To contain (and deny) the diversity of this category, colouredness was defined by white anxieties over miscegenation in colonial South Africa (Adhikari, 2005; Erasmus, 2001). Characterizing coloured people as only the children of 'mixed' relationships erased their historical claims to both Indigeneity and surviving slavery (Adhikari, 2005; Erasmus, 2001). Since apartheid's racial hierarchy positioned coloured people between 'white' and 'black', they also benefitted from anti-black racism, particularly the violent removal of black families from the Western Cape to their so-called Eastern Cape 'homelands'. Colonialism and apartheid transformed coloured people into the 'rightful' inhabitants of the Western Cape first in practice and later in law. The Coloured Labour Preference Policy [1955] sought to build a 'coloured nation' in the Western Cape through the forcible exclusion of black people from housing and employment. In the post-apartheid era, South Africans' daily lives are still divided by apartheid's racial project, and my interlocutors used the categories of black, coloured and white to speak about experiences of racism. 
After meeting Sophia in Ceres, the Black Sash and I invited her to drive the $100 \mathrm{~km}$ to the nearest Net1 office to investigate where her grant money had gone. As we travelled, the Western Cape's agrarian political economy came into sharp relief in the glaring-hot sunshine. On the road, some workers huddled together on battered trucks, as labour brokers shuttled them between orchards. On the roadside, ladders descended from trees and leaves rustled, as other workers picked ripe fruit in triple-digit heat. During this journey, it became clear that one of the ways South Africans had been racialized was through debt. Whereas Deborah James and Dinah Rajak (2014) have argued debt was central to labour discipline, I build on their analysis to demonstrate how debt was also a key part of South Africa's racial project. Sophia spoke of how debt had long been part of the racialization of coloured people: she said to me: 'people like you' (white academic) go to work and bring home money, while 'people like me' (coloured farmworker) go to work and bring home debt. Elaborating the 'moral power of money' (Wilkis, 2017), the struggle over labour, for Sophia, was not only about a wage, but critically to whom that wage belonged. As a coloured woman, she never felt she was a 'free' worker because she was always indebted to her employer.

Sophia centred debt in the founding narrative of political economy, tweaking Marx's (1990 [1867]) theory of 'so-called primitive accumulation'. Marx described the ironic doublefreedom in Europe's transition from feudalism to capitalism: 'freed' from their bondage to land, peasants-cum-workers were 'free' to sell their labour on the market. Yet, even this socalled freedom did not hold in South Africa. From the arrival of the Dutch East India Company, European settlers struggled to transform indigenous Khoi populations into workers, who resisted their efforts. This labour 'crisis' was resolved by the dispossession of Khoi land and lifeways, and the importation of enslaved people from across the Indian Ocean. With the abolition of slavery in the Cape Colony (1834), Parliamentary Hearings and Colonial Commissions ${ }^{12}$ bemoaned the so-called labour question, asking what new system of oppression could compel people to sell their labour to white industry and agriculture? Formerly enslaved people were not 'free' to sell their labour on the market, but 'apprenticed' to their former owners for at least four years. Slave owners justified this apprenticeship period through the civilizational discourse of 'cultivating the skills' of their workers for a modernizing economy. The costs of ending slavery, of a juridical transformation from property to personhood, were not sought from the Empire, ${ }^{13}$ but extracted from freed workers as an ongoing debt of labour. ${ }^{14}$

After centuries of dispossession by European conquest, Indigenous Khoi people were likewise compelled to join freed men and women as labourers on farms. Farmers used racist legislation and debt to conscript the labour of coloured people at extremely low wages. With the discovery of diamonds (1859) and gold (1886), coloured workers could get jobs on the mines, railways or harbours for triple the pay of farms (Scully, 1987). However, the Masters and Servants Act [No 15 of 1856] ensured coloured people could not move freely around the country to take up these better opportunities (Ross, 1983). By criminalizing coloured people for leaving Cape farms, employers had leverage over their workers. They exchanged lodging on their property for waged labour during peak seasons, demanding $84 \%$ of wages in housing debts (Scully, 1987). They also paid 'advances' at the end of harvest season, guaranteeing that coloured workers would have to repay their debts with labour the following year (Scully, 1987). The temporality of labour remuneration transformed workers into perpetual debtors: while farmers paid workers after their labour was consumed, workers had to pay farmers for their housing and subsistence upfront. Farmers benefitted doubly from the primary exploitation of productive capital and what Marx (1991 [1984]) called the 'secondary exploitation' of finance capital. Farmers captured the surplus value produced by 
workers, and then captured the interest on debts that workers contracted to secure subsistence.

Perversely, farm owners made these relationships of debt appear benevolent. Paralleling Lugard's (2013 [1925]) 'dual mandate', Afrikaans-speaking farmers built their cultural identity upon the cultivation of land and the custodianship of people in South Africa (du Toit, 1993). To be a farmer was not only to own a farm, but to establish relations of 'understanding', a euphemism for dominance by white authority, between 'Master' and 'Servant'. This 'understanding' was rooted in racist notions that coloured workers were lower down a Morgan-esque (2019 [1877]) civilizational hierarchy. They were deemed childlike, unable to care for themselves, and in need of protection. Farmers characterized their provision of room and board to their workers not as debts, but civilizational 'gifts', showing them how to live 'properly'. Farm paternalism used Christian morality to disguise the inherent violence of such Maussian 'gifts' and the obligations of unfree labour placed on coloured workers in return. The racializing project of South African farms inverted the violence of debt and claimed it as care.

Today, the South African economy has a surplus not a scarcity of labour. From the nineteenth century, South Africa's economy was predicated upon a concentrated system of mineral and energy exploitation by white, mostly English-speaking capital. Much of the rest of the South African economy - like agriculture, transportation and finance was developed to support these sectors to the detriment of a broader program of industrialization (Fine and Rustomjee, 1996). The end of apartheid and the integration of South Africa into the neoliberal global economy in 1994 stimulated a period of 'jobless' growth. Mines and farms laid off thousands of permanent workers, only to hire back a fraction of them on casual contracts. South Africa's official unemployment rate has grown since democracy and is now upwards of 30\% (StatsSA, 2018). While debt is no longer necessary to compel labour at low wages, it has a vital new role in social, political and financial life.

Sophia drove this point home. Hearing an ambulance siren, she grabbed my arm and said: 'They're going to the farms'. Sophia's 16-year-old son, Ardiel, was working on a farm bringing in the harvest. Under the merciless summer sun, Ardiel had twice collapsed from heat stroke and high blood pressure. Two months earlier, the ambulance had been for him and now Sophia panicked at the sound of sirens. Sophia enlivened Marx's (1990 [1871]) description of the 'surplus value' created by workers in excess of what they are paid: 'They make money off him. They break his body and he sees little money'. Ardiel worked for a middle man who sold his labour to different farms in the area. This labour broker assumed the functions previously undertaken by farmers for their workers: providing room and board as debts that are put 'on book' (recorded) throughout the month. Upon payment by the farmer, the labour broker would deduct his commission and his workers' debts before distributing their wages.

Farmworkers like Ardiel exchanged paternalistic labour relations for 'free' but precarious casual employment with labour brokers. While coloured workers were purportedly freed from peonage by white farmers, they now are subject to violent patron-client relations with labour brokers. Sophia holds herself responsible that Ardiel labours under such debts. When Sophia's grant was taken in loan repayments, Ardiel 'hopped a lorry' and ran away to the farms. She recalls: 'He told me, "mommy, you can't borrow from this one and that one." Ardiel's labour was incorporated within an ongoing, though everchanging, racial financial capitalist system. Because of the deep ties between race, labor and debt, he could not earn enough money to assist his mother. These multi-generational 
stories of unfree labour reveal how debt is constantly reformulated to racialize, dispossess and devalue coloured workers, who never receive an unencumbered wage.

\section{Racial finance capital and social grant debt}

Though the social welfare system is a socially protective response to the devastations of unemployment, it also enables the ongoing racialization of black and coloured people through debt. Apartheid had two major welfare programs: old-age pensions and family maintenance grants that were paid at racially differentiated rates. To shore up waning apartheid power in the 1980s, old-age pensions were slowly equalized between black, coloured and white people. The democratic government inherited this relatively equal pension system, retaining it mostly unchanged. Family maintenance grants were a different matter. Under apartheid, maintenance grants were paid at racially differentiated rates to white and coloured mothers and excluded black mothers altogether. Over time, other state subsidies ensured white mothers no longer needed these grants, and by the democratic transition, they were almost exclusively provided to coloured women. The post-apartheid state scrapped these obviously racialized family maintenance grants and replaced them with purportedly 'non-racial' child support grants. Yet, just as black people were included in this program and constituted the majority of it - payment rates were diminished to a fraction of apartheid's maintenance grants, lower than the lower bound poverty line. Cited as a lack of affordability by the state, this amounted to an aggressive devaluation of black and coloured women's care work.

Compounding this exploitation, the government excluded working-aged unemployed adults from social protection. Grants are allocated to individuals - caretakers of children, elderly and disabled people - but often comprise the only income available for households and families. The government only provides grants for 'deserving' individuals on the basis of their 'legitimate' exclusion from the workforce. Structurally unemployed 18-59 year olds are deemed undeserving of social support. Working precariously, if at all, unemployed adults survive by living with their grant recipient mothers or grandmothers. By excluding 1859 year olds, the government forces black and coloured women to use their individual entitlements to provide family care and drives them to money lenders to cover household essentials.

Previously, the only loans available to grant recipients came from community savings schemes, neighbours and loan sharks. Yet, from 2012, a new type of lending was made possible by the grant system. SASSA contracted CPS, a subsidiary of Net1, to pay grants. Under this contract, Net1 registered all recipients, collected their biometric information, and opened 10.5 million $^{15}$ bank accounts for them en masse. With 10.5 million exclusive clients, Net1 created subsidiaries specializing in financial products targeting this market. Claiming to be 'including' people previously excluded from finance capital, Net1 effected a major financial coup: instead of grants providing monetary assistance to poor households, loans extracted value from people whose only asset was their monthly social entitlement. As with the labour relations described above, grant recipients were represented as risky and inadequate financial subjects and deprived of control over their grants. Because of this misrepresentation of risk, Net1 conscripted grantees to high-interest credit and, through their proprietary distribution system, ensured they were systemically prevented from defaulting (Torkelson, 2020).

Net1's grant payment racialized grantees through their digital and physical banking spaces, and the way these articulated with one another. This is illustrated most vividly through Sophia's experience. Sophia had heard about a car that visited her village monthly 
to give loans. She joined dozens of queueing applicants and met Sizwe, a Net1 consultant with an aluminium briefcase. This was the same familiar briefcase - housing a computer, card reader, fingerprint scanner and receipt printer - that CPS consultants used to pay social grants. Sophia stressed how this briefcase made her feel that she was borrowing money from SASSA or a company SASSA endorsed. Instead of being stationed on a table at an official paypoint, the briefcase was positioned on the trunk of a vehicle. Sophia stressed the mobility of Net1 (and its briefcase) compared to her own: 'They come to us. They set up their machines from the boot (trunk) of the car. But, we cannot go to them'. While she was still emplaced by the 'sedentarist metaphysics' (Malkki, 1992) of apartheid and could rarely afford to leave her village, Net1 used mobile infrastructure financed by the state to transcend these restrictive spatialities. Grants were distributed at the start of each month, after which Net1 consultants travelled around like old-fashioned door-to-door salespeople, showing up where grant recipients live to offer loans.

While Sizwe and his briefcase were seen as trustworthy because of their association with SASSA, Sophia had no such credibility. Sizwe told her that her thumb must 'pass the test'. Only a biometric signature could be trusted to prove that she was part of the community of social grantees as yet unencumbered by debt. Both Net1 and the South African government wanted to attach biometric security to social welfare payment because grantees were imagined to be financially illiterate at best and artful fraudsters at worst. For example, one Parliamentarian stressed that social grantees needed biometrics because the elderly could not remember their PIN numbers. ${ }^{16}$ A bolder Parliamentarian stated a baby could be 'recycled if we don't do one-to-many checks'. Statements of this type presume grantees are potential scammers: i.e. mothers who register the same child twice or children who fail to register their parents' deaths to receive more money (Donovan, 2015). To combat such abuses, the government and Netl agreed that grantees must offer 'proof of life' materialized as their fingerprints - every month. Despite the hype, Net1's technology only does one-to-one checks to verify identity, not one-to-many checks to prevent multiple registrations. Though technologically inadequate for the government's stated purpose, Net1 claimed its biometrics excluded criminals and assisted grannies while saving the government millions. In fact, most of this savings came from the registration process itself, which was inaccessible to some former grantees (Donovan, 2015). ${ }^{17}$ By marking people as 'risky' or 'criminal' actors, Net1 was authorized to develop a system of credit that reduced grantee control over their own money.

The biometric system helped Net1 sell loans and other financial products (like insurance, electricity and airtime) without informed consent. Sophia told me that, although she only asked Sizwe for a loan, she was compelled to open another bank account with EasyPay and a funeral plan with Smartlife (both Net1 subsidiaries). She did so by repeatedly putting her thumb on the biometric scanner, unwittingly consenting to three transactions. Only after registering for these spurious products was her R1000 loan approved, repayable in six R220 instalments. Sizwe did not tell her about the Terms and Conditions of her new EasyPay account. She was only told to 'use this green card' (EasyPay card) instead of the 'white card' (SASSA card) from now on. She did not know that her social grant would be transferred to this account each month or that this account was outside SASSA's purview, exclusively within Net1's private domain. She also did not know that the EasyPay account would allow her creditors to be paid before she was. While Sophia's grant was only transferred onto her EasyPay card when she offered 'proof of life' on the first of each month, her creditors were paid temporally prior to the arrival of money in her account. This could happen because the National Treasury transferred billions of rands to Net1 for grant payment a week before Net1 transferred money to recipients. 
Net1 did not just allow its subsidiaries early and automatic payment from grantee accounts, but other microlenders as well. Even with this loan, Sophia still did not have enough money to care for her family. She needed clothes for her older children and diapers for her baby. Sophia visited XY Money Loans, a dubious payday lender with a hastily printed canvas sign, situated in a large shop partitioned by plywood. Loan applicants queued on one side of the partition, and lenders peered through four small holes on the other. A sign advertising loans for 'SASSA card-holders' misleadingly suggested their affiliation to SASSA. To apply for a loan, Sophia had to have an EasyPay or a SASSA card to access credit because Net1 ensured early repayment. Sophia took a small loan from XY Money Loans (R256 payable in two R256 instalments). The stated interest was 50\% per month, but XY Money Loans took over R3000 from her account across four months. Net1 did not flag this illegal activity, allowing XY Money Loans to repeatedly make fraudulent deductions. Sophia had no control over how these funds moved through her account.

Similarly, Net1 asked Sophia's neighbour Joseph to use his home as a venue for product sales. They knocked on his door and asked him to gather his friends who 'needed help'. The phrase 'needed help' offended Joseph because what he got from Net1 was not help but debt. He was angry that the Net1 consultants characterized themselves as aid workers providing assistance to social grantees. Joseph said he was initially wary of Net1 and questioned their motives: 'They said they are legal otherwise they wouldn't have access to the machines to activate the cards. They told me they are from SASSA'. Again, the briefcases conveyed the appearance of government authenticity, so he gathered about 15-20 people at his home to get the 'help' Net1 offered. He explained: 'They showed me the green card [EasyPay], took my fingerprints and I got my card. It took 20 minutes. My sons also got the green cards. They needed shoes and clothes and the house rent was also expensive'. Joseph's two adult sons both receive disability grants: one of his sons has cerebral palsy and the other had a stroke while working on a farm. Joseph is their legal guardian and felt pressured by Net1 consultants to accept debt on their behalf.

A long-time agricultural worker, Joseph compared the 'help' he received from the farm owner to that of the social grant system. For most of his life, Joseph lived on a farm and grew his own food. He now works at the grocery store Spar, though he should be retired. He said, '[The manager of] Spar asked me to come work [there] because they needed someone. I needed a job. I was struggling. In the old days, I could go to Fanie (farm-owner) and say "give me a few potatoes." Now I have to buy potatoes. Before I could say "Fanie, give me an apple," now I must buy it. Everything that I want, I have to pay for. I have to lend money to pay for it. I can't ask SASSA for a potato or an apple'. For Joseph, the paternalism of farm labour meant that owners often treated workers as part of the household. Whilst a system of deeply unequal obligation, workers could ask for assistance in times of need. Joseph remembers the intimacy of this relationship, not fondly, but as a notable contrast to Net1. He compared Net1's digitized debts with the paternalistic debts on the farm, which though exploitative, were negotiable and personal, not automatic and anonymous. Once Joseph had applied for a loan and insurance policy, there were 'extras' deducted from his grant every month without explanation. He too had little control over how his money moved through his account.

When Sophia and Joseph applied for loans, they made repayments from income earned through social welfare, not wage labour. This confounds Marxist interpretations of credit as a claim on future labour, typically referring to economically productive work (Harvey, 2006 [1982]). Grantees did not borrow on the basis of future waged labour (or past waged labour, as in the case of contributory pensions), but on future social reproductive labour valourized by the government through the grant system. Because Sophia and Joseph used their loans to 
pay for things that should be provided by the national social protection framework - food, rent, healthcare - there was no way for them to repay their debts through income earned on an investment or asset. Whilst this is a popular myth of poverty finance, during three years of research, I only met one person who started a business with a loan secured by a social grant income. Everyone else repaid their debts by borrowing more or consuming less the following month. Sophia and Joseph metabolized their loan repayments in future months, as the very social entitlements intended to support life disappeared to repay debts. ${ }^{18}$

Marked as 'risky' financial subjects, these racialized and gendered grantees became a sure bet for lenders. The grant formed a promise between the citizen and the government, generating a surety that was as reliable as permanent employment. Netl's proprietary technologies and physical access to grant holders allowed them to aggressively market their products. Net1 built a biometric system where consent for credit could be achieved with a grantee's thumbprint. Net1 controlled all the necessary information on grantees, and knew when a temporary grant lapsed or when a child turned 18. Net1 knew how grantees spent their money, and if they had any other liabilities on their accounts. Net1 also controlled the entire grant payment stream from the National Treasury to grantee bank accounts: they distributed social grants, offered loans on social grants and recouped payments from social grants - all before so-called beneficiaries could access their money. There was no oversight from the National Treasury or the Reserve Bank because this occurred as a series of proprietary internal transactions within Netl and its subsidiaries. Reformulating the racial finance capitalism of previous eras, grantees could not default on their loans by choice or mistake because they had incomplete control over their money. The only risk of nonpayment occurred in death, when the state would stop paying a grant to a beneficiary.

\section{The multivalence of debt}

Much work on debt sees it as an individualizing force because of the shame associated with owing money, but movements like Occupy, Strike Debt and Jubilee have focused on the collective experience of indebtedness (Graeber, 2012). Similarly, Sophia and Joseph used the multivalent meanings of debt to challenge their ongoing vulnerability to racial financial capitalism. Sophia asserted: 'Our money should be ours, but they take it like it's theirs'. The juxtaposition of the possessive pronouns 'ours' and 'theirs' focused attention on ownership of the grant. Sophia felt the grant should be 'hers', but her creditors made it 'theirs' instead. Credit, under the tyranny of capitalism, creates debts in the present which mandate repayments in the future. Her creditors used financial technologies to present certain 'truths' - measured in interest rates and fees - to demonstrate that Sophia owed them money. Her debts allowed her creditors to position themselves as the rightful owners of her social grant. But, Sophia rejected this claim, positioning herself as a net creditor to the nation, owed a debt for the labour, land and life she and her forbears rendered to white farmers. Sophia challenged the morality and directionality of her debts, claiming that new debts could not be attached to money meant to alleviate the poverty and inequality cultivated under centuries of white minority rule. Sophia's understanding of debt was manifold - economic, political, moral, social and generational - allowing her to make claims for social justice, by drawing attention to the dynamics of racial financial capitalism.

Joseph, too, tied his social grant debts to his personal history of dispossession on three previous occasions. His first dispossession was before he was even born on a farm near Ceres. His parents and their parents had their land stolen and were indebted farmworkers beholden to a white farm owner. From the time he was a child, he too had to work for the white farmer in repayment of his parent's debts. He got married 'on the farm', had children 
'on the farm', and raised his family 'on the farm'. Despite having lived there all his life, his second dispossession occurred in the early days of democracy, when he was evicted from the farm and forced to build a shack in a neighbouring village. Many farmworkers were dispossessed during this period because owners feared post-apartheid laws would give their workers tenure security on what they perceived to be 'their' property (du Toit and Ally, 2003). His third dispossession came when Joseph was selected to be part of an agricultural 'empowerment' project. He was one of the only farmers in his area given a small plot under a Department of Agriculture program to diversify land ownership. He threw everything he had into that plot to make it successful but a politically connected stand-over man stole the money intended as Joseph's start-up capital. Joseph tried to borrow money to get the farm going, but ultimately the land was taken away because he had not developed it in accordance with the program rules.

Joseph understood the financialization of social welfare as his fourth dispossession. He reflected, 'I think if I had my own farm, things would go better. But that money never came to me. And now again, they taking it from me. Nothing comes to me as it should come. It comes only halfway and goes into a dead end'. Joseph expressed how, as a coloured person, he has never had control over money designated for him, which only ever comes 'halfway'. Instead of retiring, Joseph works a part-time job at the supermarket packing the produce that he used to grow. Joseph linked his experience of dispossession to accumulation, and specifically white (and increasingly black) capitalists in South Africa, who consolidate their wealth through stolen labour, land and financial assets. The thefts Joseph endured did not end with the transition to democracy but continue to buttress a vastly unequal society today.

Given their familiarity with being made into debtors, Sophia and Joseph both attempted to contact Net1 to find out why they were not receiving their money. Although Net1 supposedly 'banked' the unbanked poor, they did not offer the same kind of support as traditional financial services. Net1 only had 144 permanent locations throughout South Africa. Given this limited infrastructure, Netl's 'mobile solutions' were meant to be accessible and appropriate for grantees. Technological boosters assume everyone has a mobile phone (Aker and Mbiti, 2010), but many people in the farmlands use a SIM card in a neighbour's device. When Sophia and Joseph called Net1, they could not get 'help' because they ran out of airtime, forgot answers security questions or failed to connect with an Afrikaans-speaking consultant. Technologies meant to make banking accessible from anywhere instead made it inaccessible from everywhere.

Failing to use Netl's mobile infrastructure, Sophia's only option was to wait until Sizwe arrived two weeks later. Net1's monthly visits structured time in her village as many people needed loans and those who had them often had questions. Sophia went to Sizwe and demanded to see her bank statement. In October, Sizwe said he could only print out the last few transactions on a partial receipt. He would have to request a comprehensive statement from the head office and deliver it the following month. In November, Sophia's account was drained again and she returned to Sizwe. 'He forgot. He never brought that statement. He said he'll bring it next time'. In December, the same happened again. 'Sizwe asks me, "why do you need the statement? You won't be able to read it anyway. You're a farmworker." Sizwe told her to stop 'being clever' and to stop 'making a scene'. Sizwe never recorded these interactions, so there was no proof Sophia asked for a bank statement for three months. Instead, she told me: each month, 'I start arguing with him again, like it's the first time'.

The racial paternalism of this encounter worked alongside the digital and physical limitations of Net1. She tried but failed to use Net1's 'mobile solutions' to seek recourse because she did not have access to a phone. This reinforced racial hierarchies, where 
technologies are used to mark 'civilizational' distance between people. Her personal interactions with Sizwe encoded histories of Western Cape slavery and exploitative labour relations always resulting in debt. Capitalizing on apartheid's racist spatial order, Net1 moved around the country, consulting with clients from the trunk of a car; but Sophia stayed in her village, awaiting his visit. Net1 was meant to appear accessible, returning to each village like clockwork; but its consultants barred grantees from seeking recourse. Sophia's persistence upset Net1's self-narrative of a humanitarian tech company, and Sizwe resorted to paternalistic tropes to bind Sophia to 'her place' and discipline her behaviour.

\section{Roadtrip recourse}

Sophia and Joseph turned to a local social justice organization for assistance - that is how the Black Sash, the film-makers and I met them in Ceres. They wanted to find out what was happening in their bank accounts and take part in our film. Sophia rode with me and Joseph with the film-makers as we caravanned to Net1's nearest office. When we arrived, we went in separately so as not to arouse suspicion. Netl was a large, open room that looked like a high school cafeteria hosting a career fair. There was a long table across the front of the room and smaller ones on the sides, draped in banners from EasyPay, Moneyline and Smartlife. Sophia went to a consultant and requested a bank statement. She was instructed to take a seat and wait for someone from 'the back'. We noticed the space was larger than it appeared, with a door and a one-way mirror along the front wall. We learned that the front room was available for public processes, such as opening new accounts and accepting new products, while the back room was reserved for private processes, like dealing with complaints and managing anything unsavoury. The designation of one section as public and another as private imposed a spatial ordering of power within the office and on the movements of clients and consultants. Some kinds of knowledge were rendered permissible in some spaces and some were not. Sophia had to be excluded from the public operations of the business for the problems to be continually hidden.

Once in 'the back', we met Anthea, a young coloured consultant, seated in a storage space surrounded by stacks of aluminium briefcases. Sophia explained her inability to get a bank statement and complained of the treatment she received from Sizwe. Anthea looked at us knowingly, and said: 'Ohhhh. Sizwe. I've heard about him'. Anthea's tone transformed Sizwe into a rogue, excising him from the 'normal' functioning of the business. One of the goals of accounting has been to create systems that cannot be altered by individuals, making all employees seem interchangeable and capable of conveying institutional authority (Poovey, 1998). But, such goals are never fully realizeds (Poovey, 1998). In this case, Anthea alluded to the hierarchy among Net1 workers. Travelling consultants were far from the supervision of the main branches, so there was no way to oversee their behaviour. Sizwe's retention with Net1 depended on his ability to meet monthly sales targets. Net1 used Sizwe to ensure clients were conscripted into debt, and used his role as a 'fieldworker' to give them plausible deniability for predatory practices.

Initially, Anthea told us she could not print Sophia's bank statement because the person with the computer login details had gone home. While we continued to sit in her office, Anthea made several phone calls and finally printed the statement. She looked at the paper, highlighted transactions in pink, and explained her version of events. She told us that Sophia went to the wrong lender: 'This XY is not good. We see them all the time'. She pointed to her highlighting: in October, XY Money Loans made seven different debit orders; in November, three; and in December, five. Eleven of the debit orders were for the exact same amount of money (R256), which Anthea called a 'red flag'. She concluded 
that these deductions were fraudulent. Sophia asked if EasyPay could stop or refund these transactions. Anthea shook her head. According to Net1, Sophia must report fraud within 40 days for the transactions to be refunded. Sophia protested that she did report the fraud, through Sizwe, but there was no proof. Anthea told Sophia to get her contract from $\mathrm{XY}$ Loans, open an investigation with the police, and bring these documents to this office for a refund.

Although Anthea had concluded the deductions were not Netl's fault, she was holding the statement tightly. A bank statement gives the illusion of transparency, a list of simple equations that seem objective and true. But Anthea was concerned about the potential power of this ledger, and what we might deduce from its contents. She controlled how we read it with her highlighting, drawing our attention to XY Money Loans. She attempted to make Netl's profits on the XY loan invisible (overdraft charges, EFT reversals and insufficient funds requests). She also attempted to distract us from the hundreds of rand Moneyline and Smartlife (both Net1 subsidiaries) deducted every month from Sophia's account as well. Anthea claimed Net1 was much better than lenders like XY Money Loans, yet Net1 enabled deductions by all lenders without protection for Sophia. A technologically savvy corporate system is not necessarily better than a loan shark, if it facilitates thefts by loan sharks. Because Sophia was unable to report this fraud properly, due to Net1's own deficient system, there would be no recourse. This bank statement did not 'help' Sophia, but papered over deep inequalities, experiences and knowledges.

Whilst with Anthea, we tried to ensure Sophia would receive her full grant the next month. We asked if we could pay off her loan and cancel her EasyPay card - but, we were not able to do so, despite Netl's Terms and Conditions saying otherwise. For the loan, we asked Anthea how much Sophia still owed. Anthea made several more phone calls to the person with the 'right' computer access and told us Sophia owed R660. We were not able to pay this amount at the Net1 branch because they would not handle cash, but at another bank around the corner (which we did). Anthea warned Sophia's loan would not stop immediately, since there was no real-time reconciliation on their computer system. No one had ever paid early before, so there was no process for it. Anthea said Sophia should not close her EasyPay card; otherwise, she would not get reimbursed. Money would be deducted this month, as the payroll had already been loaded into the system, and the repayments would only stop next month. Anthea wrote down Sophia's details, promising to follow-up. This call never came.

Afterward, Sophia and I learned that Anthea had behaved similarly with Joseph. But, instead of diverting attention to XY Money Loans, she told him One Life Insurance was deducting most of his money. There were several policies coming off his account every month, for which Net1 claimed no responsibility. Joseph adamantly refused that he contracted these policies. When we phoned One Life to inquire, the consultant told Joseph that his son, Elton Daniels, signed him up for the policies. Joseph explained that while he had sons, neither was named Elton, and neither could sign contracts on his behalf. One Life, of course, could not take his word for it, and needed police affidavits swearing to their disabilities, before they would agree to cancel the policies. That would take a separate $100 \mathrm{~km}$ trip.

After visiting Net1, we went to XY Money Loans and tried a different tactic. Sophia went into the shop alone, while the film crew waited outside. Through the windows, we watched her argue with a teller for 10 minutes, getting nowhere. Then, the film-makers moved their cameras closer, filming the interaction through the doorway. Suddenly, a manager appeared, consulted Sophia's bank statements and returned with cash. Sophia came out of XY Money Loans brandishing over R3000 - the entire amount deducted. I asked how she 
felt. 'Gatvol! (Fed up!) It was the cameras'. She asked if it would always take a film crew to sort out debts levied on the poor? At the end of this experience, Sophia was not grateful for getting her money back. She was angry. Net1 tried to monopolize moral righteousness, but Sophia introduced her own moralizing discourse. The work of financializing a social grant became a terrain of struggle, where very different notions of debt and debtors come into being.

This is related to James Ferguson's (2015) analysis about a new politics of distribution emerging around social grants in Southern Africa. He argued that the vast majority of Southern Africans are structurally unemployed and have been 'cut out of the distributive deal' of wage labour (p. 38). Rather than proposing productive-centric policies like job creation, Ferguson suggested that more radical forms of distribution, de-linked from labour, could provide a way of 'cut[ting people] back in' (p. 38). A universal grant, instead of stigmatizing poor recipients, might enable new forms of demands, where all people present in South Africa might claim a portion of the national wealth. Whilst this is an interesting argument, South African grants are not universal, and the claims being made on the ground are somewhat different than Ferguson describes. Ferguson does not adequately explore questions of economic power and historical disadvantage in his analysis. He argues that more equitable distribution can be achieved through a broad, cross-class consensus and an effective tax system: i.e. national budgets can be rejigged to provide more substantial social protection. But, in this equation, extant power structures could remain intact, and racial finance capital could continue to profit from an even more generous redistribution program. The poor have, of course, always been targets of financial abuse, but the conjunctural moment of low unemployment and aggressive growth in financial markets, makes them particularly vulnerable to predatory debts.

Contrastingly, my interlocutors were adamant that given the long durée of racial financial capitalism in South Africa, universal basic income was both necessary for survival and insufficient to affect repair. For Sophia and Joseph, their demands were not only about changing the national budget to demand a redistribution of wealth, but to force a national reckoning with racial financial capitalism. Like Best and Hartman (2005), who insightfully elaborate the difference between reparation and repair, my interlocutors' demands suggested that though they needed social grants, that money was vastly inadequate and could never repair what was broken over centuries. Sophia and Joseph recognized how the spatiality and temporality of the Net1 grant payment system foisted debt onto grantees and, they recognized how Net1's profits depended on the re-formulation and re-institutionalization of racial injustice. In response, they narrated their multi-generational conscription by racial finance capital to debt, even as the theft of their land and labour served as a net credit to a series of racist nation-building products. Sophia and Joseph's critiques suggest that as long as this system of racial financial capitalism stays intact, the grant itself, or any other redistribution program, has the potential to become another indebting and dispossessing force. Redistribution that does not challenge structures of power can continue to give with one hand and take with another. While South Africa's social grants are rightful and deserved, they are also partial and cannot fulfil Sophia and Joseph's desire for repair.

\section{Conclusion: Gallant's rebels}

In this article, I traced a racial history of debt in the Western Cape farmlands. Developing the term racial finance capitalism, I showed how coloured South Africans have continually been deemed unfit financial actors unable to 'own' their land, labour or wages. As the South African economy has de-industrialized and de-agrarianized since the 1970s, finance capital 
has been one of the only growth sectors. With high unemployment, the security of social welfare payments allowed recipients to be brought into punitive credit markets and predated upon by formal loan sharks. Black and coloured women, excluded from the labour market, were revalued and exploited by finance capital through their receipt of a social wage. Net1 converted these social entitlements from the state into lucrative gains for creditors through the temporalities and spatialities of a vastly unequal grant distribution system.

Grantees did not passively accept this debt, but contested it. These contestations did not take the 'typical' form of South African protest - boisterous toyi-toying (protesting) on the street - but rather conversations at community meetings, in loan queues and over bank statements. Recipients offered trans-generational critiques of indebtedness, explaining how debt has been attached to particular racialized people in South Africa across time. In so doing, they refused the ongoing reproduction of coloured and black people as debtors, recalling the ways they have financed the nation. Recognizing themselves as creditors, Sophia and Joseph challenged the financialization of the very program meant to offer slight relief from abject poverty. The Black Sash witnessed these stories and fought three lawsuits against Net1 alongside social grantees. In 2018, this advocacy work led to a significant change in the way grants are paid, bringing distribution back under public control through the Post Office. Whilst this has not been without challenges, over $70 \%$ of grantees now have bank accounts that do not allow exploitative automated deductions. Even so, as Sophia and Joseph would add, this sort of program is essential for survival, but will always fall short of repairing the injustices of the past.

Inspired by my interlocutors' trans-generational analyses, I will end with a reflection from one of the film-makers, Johan Abrahams. After a long day of filming, he asked: 'the Gallant Rebellion happened here. You heard of it?' He recalled how in 1825, an uprising occurred just up the road. Gallant van der Caab led enslaved and free workers in a revolt against a white farmer, who denied them independence. Johann stressed that, like their debt, Sophia and Joseph's resistance had a trans-generational history too. Whilst currently constrained by South Africa's liberal politics, their desire for more significant forms of repair, beyond the grant program, might someday be transformative.

\section{Acknowledgements}

This article could not have been written without Lynette Maart and Esley Philander of the Black Sash and many grant recipients near Ceres. Likewise, Johan Abrahams, Clinton Daniels and Erna Curry helped make this research possible. I would also like to thank Gillian Hart, Donald Moore, Sharad Chari, Leopold Podlashuc, Stephen McIsaac, Andrea Marston, Meredith Alberta Palmer, Jen Rose Smith, Alex Werth, Ashton Wesner, John Elrick, Brittany Meché, Julia Sizek and Zahra Hayat for reading drafts of this article.

\section{Declaration of conflicting interests}

The author(s) declared no potential conflicts of interest with respect to the research, authorship, and/or publication of this article.

\section{Funding}

The author(s) disclosed receipt of the following financial support for the research, authorship, and/or publication of this article: My research has been supported by the Wenner-Gren Foundation, Andrew W. Mellon Foundation and Charlotte Newcombe Foundation as well as the Center for International and Area Studies and Center for African Studies at the University of California, Berkeley. 


\section{ORCID iD}

Erin Torkelson (D) https://orcid.org/0000-0002-2345-6487

\section{Notes}

1. All names have been changed.

2. Activists fighting for labour protections started the Witzenberg Rural Development Centre during apartheid.

3. Lavinas (2018) called a similar phenomenon in Brazil the 'collateralization' of social policy.

4. I calculated this statistic from StatsSA (2018) data.

5. James (2014) describes how courts granted garnishee orders for creditors to automatically deduct repayments from salaried workers. In this case, Net1 did not need to apply for court orders because they controlled the cash flow between the National Treasury and grantee accounts and could deduct repayments at will.

6. About $25 \%$ of grantees had deductions on their accounts (Black Sash, 2016).

7. This term came from a 2018 AAG session of the same name.

8. With the exception of furniture purchases on high-interest instalment plans.

9. See Harker 2017 on spatial topographies of debt.

10. In Torkelson 2020, I focus on the digital geographies of distribution.

11. This resonates with Christina Sharpe's (2016) concept of 'wake work', and the reverberations of slavery under the 'contemporary conditions of spatial, legal, psychic and material dimensions of Black non/being'.

12. See the Transvaal Labour Commission (1891).

13. Britain offered compensation to former South African slave owners, but most could not afford the journey to the Empire to apply.

14. Saidiya Hartman (1997) has made a similar argument in the United States.

15. While there are 18 million grant beneficiaries, there are only 10.5 million recipients because some people receive multiple grants, e.g. mothers who care for two children.

16. Portfolio Committee for Social Development, 30 November 2016.

17. During the Net1 registration process, many people did not re-register for their grants. There is no way of knowing whether this decline resulted from false grantees fearing being caught or rightful grantees unable to access the system. In neither case did biometric technologies save money.

18. While I focus on coloured people here, Net1 targeted black people too.

\section{References}

Adhikari M (2005) Not White Enough, Not Black Enough: Racial Identity in the South African Coloured Community. Cincinnati: Ohio University Press.

Aker JC and Mbiti IM (2010) Mobile phones and economic development in Africa. Journal of Economic Perspectives 24(3): 207-232.

Amoore L (2009) Algorithmic war: Everyday geographies of the war on terror. Antipode 41(1): 49-69.

Appel H, Whitley S and Kline C (2019) The Power of Debt: Identity and Collective Action in the Age of Finance. Los Angeles: Institute on Inequality and Democracy.

Best S and Hartman S (2005) Fugitive justice. Representations 92(1): 1-15.

Black Sash (2016) Community based monitoring: SASSA paypoints: October 2016-November 2016. Available at: https://cbm.blacksash.org.za/survey-types/sassa-paypoint-citizen. (accessed 10 November 2020).

Black Sash (Producer), Philander E, Cousins CC, et al. (2018) Grant grabs. Cutting Edge 27 March. Available at: https://www.youtube.com/watch?v $=$ Qa97QSi8F80andt $=185 \mathrm{~s} . \quad$ (accessed 10 November 2020).

Chakravartty P and Da Silva DF (2012) Accumulation, dispossession, and debt: The racial logic of global capitalism. American Quarterly 64(3): 361-385. 
Clemence Z and MacLellan F (2017) Cash Transfers Get an Upgrade. FinDev Gateway. Washington, DC: FinDev Gateway.

Collins D, Morduch J, Rutherford S, et al. (2009) Portfolios of the Poor: How the World's Poor Live on $\$ 2$ per Day. Princeton, NJ: Princeton University Press.

Donovan K (2015) The biometric imaginary: Bureaucratic technopolitics in post-apartheid welfare. Journal of Southern African Studies 41(4): 815-833.

Dubow S (1995) Scientific Racism in Modern South Africa. Cambridge: Cambridge University Press.

Du Toit A (1993) The micro-politics of paternalism: The discourses of management and resistance on South African fruit and wine farms. Journal of Southern African Studies 19(2): 314-336.

Du Toit A and Ally F (2003) The Externalisation and Casualisation of Farm Labour in Western Cape Horticulture. Working Paper no. 16, Program for Land and Agrarian Studies. Cape Town: University of the Western Cape.

Elyachar J (2005) Markets of Dispossession: NGOs, Economic Development, and the State in Cairo. Durham: Duke University Press.

Erasmus Z (2001) Introduction. In: Erasmus Z (ed) Coloured by History, Shaped by Place: New Perspectives on Coloured Identities in Cape Town. Cape Town: Kwela Books.

Ferguson J (2015) Give a Man a Fish: Reflections on the New Politics of Distribution. Durham: Duke University Press.

Fine B and Rustomjee Z (1996) The Political Economy of South Africa: From Minerals Energy Complex to Industrialization. Johannesburg: Wits University Press.

Gabor D and Brooks S (2017) The digital revolution in financial inclusion: International development in the Fintech era. New Political Economy 22(4): 423-436.

Gilmore RW (2007) Golden Gulag: Prisons, Surplus, Crisis, and Opposition in Globalizing California. Berkeley: University of California Press.

Graeber D (2012) Debt: The First 5000 Years. London: Penguin.

Harker C (2017) Debt space: Topologies, ecologies and Ramallah, Palestine. Environment and Planning D: Society and Space 35(4): 600-619.

Harney S and Moten F (2013) The Undercommons: Fugitive Planning and Black Study. Brooklyn: Minor Compositions.

Hartman SV (1997) Scenes of Subjection: Terror, Slavery, and Self-Making in Nineteenth-Century America. Oxford: Oxford University Press.

Harvey D (2006) [1982] The Limits to Capital. New York: Verso.

Hulme D, Hanlon J and Barrientos A (2012) Just Give Money to the Poor: The Development Revolution from the Global South. Boulder: Kumarian Press.

International Finance Corporation (2016) IFC Invests in Net1 to Promote Technology That Expands Financial Services to Poor in Africa, April. Washington, DC: World Bank Group.

James D (2014) Money from Nothing: Indebtedness and Aspiration in South Africa. Palo Alto: Stanford University Press.

James D and Rajak D (2014) Credit apartheid, migrants, mines and money. African Studies 73(3): 455-476.

Karim L (2011) Microfinance and Its Discontents: Women in Debt in Bangladesh. Minneapolis: University of Minnesota Press.

Kelley RDG (2017) What did Cedric Robinson mean by racial capitalism? Boston Review 12 January 2017.

Kish Z and Leroy J (2015) Bonded life: Technologies of racial finance from slave insurance to philanthrocapital. Cultural Studies 29(5-6): 630-651.

Lavinas L (2018) The collateralization of social policy under financialized capitalism. Development and Change 49(2): 502-517.

Legassick M (1974) South Africa: Capital accumulation and violence. Economy and Society 3(3): 253-291.

Lugard LFJ (2013) The Dual Mandate in British Tropical Africa. London: Routledge.

Magubane B (1979) The Political Economy of Race and Class in South Africa. New York: Monthly Review Press. 
Malkki L (1992) National geographic: The rooting of peoples and the territorialization of national identity among scholars and refugees. Cultural Anthropology 7(1): 24-44.

Marx K (1990) [1867] Capital Vol. 1. New York: Penguin.

Marx K (1991) [1894] Capital Vol. 3. New York: Penguin.

McKittrick K (2011) On plantations, prisons, and a black sense of place. Social \& Cultural Geography 12(8): 947-963.

Melamed J (2015) Racial capitalism. Critical Ethnic Studies 1(1): 76-85.

Morgan LH (2019) [1877] Ancient Society: Researches in the Lines of Human Progress from Savagery, through Barbarism to Civilization. Glasgow: Good Press.

Noble SU (2018) Algorithms of Oppression: How Search Engines Reinforce Racism. New York: New York University Press.

Poovey M (1998) A History of the Modern Fact: Problems of Knowledge in the Sciences of Wealth and Society. Chicago: University of Chicago Press.

Posel D (2001) Race as common sense: Racial classification in twentieth-century South Africa. African Studies Review 44(2): 87-113.

Ranganathan M (2019) Empire's infrastructures: Racial finance capitalism and liberal necropolitics. Urban Geography 41(4): 1-5.

Robinson CJ (1983) [2000] Black Marxism: The Making of the Black Radical Tradition. Durham: University of North Carolina Press.

Ross RJ (1983) Cape of Torments: Slavery and Resistance in South Africa. London: Routledge.

Roy A (2010) Poverty Capital: Microfinance and the Making of Development. London: Routledge.

Scully P (1987) The Bouquet of Freedom: Social and Economic Relations in the Stellenbosch District, c1870-1900. Doctoral dissertation, University of Cape Town database.

StatsSA (2018) General Household Survey 2018. Pretoria: Government Publishers.

StatsSA (2011) Gender Statistics South Africa. Pretoria: Statistics South Africa.

Taylor KY (2019) Race for profit: How banks and the real estate industry undermined black homeownership. Chapel Hill: University of North Carolina Press.

Torkelson E (2017) Farmworker has to decide which of her children to feed. Ground Up. 15 March 2020. Available at: https://www.groundup.org.za/article/sophias-choice-farm-worker-has-decidewhich-her-children-feed/. (accessed 11 November 2020)

Torkelson E (2020) Collateral damages: Cash transfer and debt transfer in South Africa. World Development 126: 1-11.

Wilkis A (2017) The Moral Power of Money: Morality and Economy in the Life of the Poor. Palo Alto: Stanford University Press.

Wolpe H (1972) Capitalism and cheap labour-power in South Africa: From segregation to apartheid. Economy and Society 1(4): 425-456.

Wyly E, Moos M, Hammel D, et al. (2009) Cartographies of race and class: Mapping the classmonopoly rents of American subprime mortgage capital. International Journal of Urban and Regional Research 33(2): 332-354.

Erin Torkelson is a Wenner-Gren Hunt postdoctoral fellow and an Andrew W. Mellon postdoctoral fellow in Geography at the University of the Western Cape in South Africa. Her research explores the collision between normative assumptions about cash transfers as public goods and the lived experience of cash transfers as private debts. 